\title{
WHAT DIFFERENTIATES THE ENTREPRENEURS FROM NON-ENTREPRENEURS ON NATURE AND NURTURE?
}

\author{
Syed Zaheer Abbas Kazmi ${ }^{1}$ - Samiuddin Khan ${ }^{2}$ - Andras Nabradi ${ }^{3}$ \\ ${ }^{1}$ Faculty of Economics and Business University of Debrecen, Hungary \\ Faculty of Management Sciences, National University of Modern Languages (NUML), Islamabad Pakistan \\ zabbas@numl.edu.pk \\ ${ }^{2}$ Swat College of Science and Technology. Mangora Swat, Pakistan samiuddinkhanbabar@gmail.com \\ 3Faculty of Economics and Business, University of Debrecen, Hungary \\ nabradi.andras@econ.unideb.hu
}

\begin{abstract}
Based on the importance and contribution of entrepreneurship in economic development, it is vital to know that what underlying factors may promote the spirit of entrepreneurship? The entrepreneurship literature suggests two kinds of broader influencers or predictors for entrepreneurs and non-entrepreneurs "nature" and "nurture". In this study "nature" includes the psychological or personality related factors; self-confidence, locus of control, risk-taking propensity and trust levels. The "nurture" is explained by the effects from society in general and friends and family in particular. To answer the question "What differentiates the entrepreneurs from non-entrepreneurs on nature and nurture?" we collected data through questionnaire from 155 respondents. The 70 respondents were entrepreneurs and 85 were non-entrepreneurs. Step-wise discriminant analysis was used to determine the discriminating factors for entrepreneurs from non-entrepreneurs. Results indicate that societal impacts, risk taking propensity and trust levels were significantly discriminating the two groups; entrepreneurs and non-entrepreneurs. The study has important implications for policy makers, academicians, researchers and potential entrepreneurs.
\end{abstract}

Keywords: self-confidence, trust levels, locus of control, societal impacts, discriminant analysis (JEL Code: L26, M13)

\section{INTRODUCTION}

Entrepreneurship is one of the most vital ingredients in the economic development of a society. As in developing nations, small and medium scale businesses are the main sources of income generation, job creation and poverty alleviation. Entrepreneurship is essentially important for the economic development of every country (Amiri and Marimei, 2012) As per the Government of Pakistan's Small and Medium Enterprises Development Authority (SMEDA), (2017) SMEs in Pakistan are about $90 \%$ of all the enterprises; they employ nearly $80 \%$ of the non-agricultural labor force of the country; and they contribute approximately $40 \%$ share to the annual GDP. Pakistan has enormous entrepreneurship potential. Entrepreneurial activity is however limited mainly for the lack of government policy (Chemin, 2010), Socio-cultural constraints (Muhammad et al, 2017), financial and other barriers (SMEDA 2017), and also, the entrepreneurship education is mostly focused on "about entrepreneurship" in the developing countries (Kazmi and Nabradi, 2017). The education about entrepreneurship makes the students aware about entrepreneurship by providing overview and orientation; it however has less impact on creating entrepreneurs.

Many authors have defined entrepreneurship in different perspectives. The word "entrepreneur" originates from the French verb "entreprendre" (Kirby, 2004). It appeared in the French dictionary in 1723 (Kates, 2015). Richard Cantillon (1730) viewed entrepreneur as self-employed and bearer of uncertainty. Since the year 1730, there have been many definitions of entrepreneur and entrepreneurship. The debate that entrepreneurs are born or made can long be traced in the entrepreneurship research literature. The trait theories of entrepreneurship hold the notion that entrepreneurs exist because of their entrepreneurial traits or personality characteristics or traits. This thesis can be termed as the "nature" of entrepreneurs. The behavior theories of entrepreneurship hold that entrepreneurs are made because of the society. This view about entrepreneurs stresses upon the "nurture" of entrepreneurs. Despite a large body of research on the trait and behavior or nature and nurture of entrepreneurs, this study has made significant contribution as in some cultures, some of the trait and behavior aspects 
of entrepreneurs were found significant and in other cultures they were not. This is evident in a recent study conducted in India by Richa (2017). Our study is conducted in a developing society - Pakistan. It is important for the body of knowledge, research community and practitioners to know that what factors hold significant for the people to become entrepreneurs from the nature and nurture aspects.

The entrepreneurship research literature is rich with the discussion on the "nature and nurture" of entrepreneurs or born versus made of the entrepreneurs. Classical theories of entrepreneurship stress the role of personality traits - the nature of entrepreneurs (Schumpeter, 1911; Knight, 1921; Kihlstrom and Laffont, 1979). Relatively new studies employing the two-group research designs to compare entrepreneurs from non-entrepreneurs emphasized greater importance on the "nurture" relative to "nature" in determining the choice to become an entrepreneur (Nicolaou et al., 2008; Zhang et al., 2009; Nicolaou and Shane, 2010). More recently, Henrekson and Sanandaji (2017) concluded that all the business owners are not entrepreneurs. In search of the true Schumpeterian Entrepreneurs, they analyzed data of 996 self- made billionaires published by the Forbes Magazine between 2010 and 2015. Owoseni and Akanbi, (2011) propose that the entrepreneurial success mainly relies on the individual qualities and the situational factors. They suggested three basic and five ancillary qualities of relatively more prosperous entrepreneurs. The three main qualities are: internal Locus of control, Risk taking behavior and Need for achievement (McClelland, 1961; Ahmed, 1985; Perry, 1986; Lorrain, 1988; Hood, 1993; Begley, 1987; Mengel, 1972; Dart, 1971; Meyer, 1961; Liles, 1974; Broehl, 1987). While the five ancillary factors are need for power, tolerance of ambiguity, Endurance, need for affiliation and need for autonomy. (Hornaday, 1970, 1982; Vesper ,1990; Wainer and Rubin, 1969; Begley, 1987; Bellu, 1987). Gartner, (1988) stated that most researchers are unsatisfied with the psychological traits approach as it is unable to define the behavior and performance of the entrepreneur. These researchers have come to the conclusion that the predictability of entrepreneurs, non-entrepreneurs, successful and failed entrepreneurs cannot be determined from the personality features of the individuals. This notion is also justified by Low and MacMillan (1988) by stating that "entrepreneurs tend to defy aggregation". Since, the contradiction between in-born and made-up entrepreneurs exists from very beginning. However, it would be unfair to attribute the success of entrepreneurial activity to either of the features. Gartner (1988) and Vesper (1980) suggest that establishing a business entity is the result of many factors. A previous research by (Sandberg \& Hofer, 1987) also claims that individual involvement and entrepreneurial success cannot be estimated from a group of variables. Similarly, other researchers have attributed diverse methods, unreliable results, different unit of analysis, and different set of samples to the failure of psychological traits approach. Still, studies regarding personalities are crucial for evaluating the entrepreneurial success being a major part of interest (Rauch \& Frese, 2000). But researchers have deduced some factors which are directly associated with entrepreneurial preferences (Koh, 1996). Three factors are regarded as the most crucial. These are moderate risk taking attitude, high need for achievement and internal locus of control (Korunka et al., 2003).

This study, encompasses five independent variables namely- self-confidence, locus of control, risk taking attitude, societal impacts and trust levels. Self-Confidence (SC), Locus of Control (LC), Risk-Taking Propensity (RTP) and Trust Level (TL) from the nature aspect of entrepreneurs. For the nurture aspects, Societal Impacts (SI) were used to determine their impacts on the career decisions of entrepreneurs and non-entrepreneurs. These variables are aimed to be tested for the two groups- entrepreneurs and non-entrepreneurs. After applying the discriminant analysis, it will become evident that which of the five independent variables significantly discriminates among the two groups.

Self Confidence is Similar to Bandura's (1977b) self efficacy. Perceived self-belief or confidence in one's own abilities to carry-out specific tasks. When people have a strong belief in their capabilities and skills that they can start and manage a business venture successfully, it does increase their chances of becoming an entrepreneur. Intellectual and nonintellectual skills can assure higher entrepreneurial success rates. It contributes substantially towards the entrepreneurial success. Self-confidence refers to the individual's trust in himself to carry on the business activities. It is regarded as one of the crucial factors in initiating and undertaking an entrepreneurial activity. In other words, individuals with high self-confidence are also likely to take relatively more risks. Entrepreneurs are generally seen as those in control of their own ambitions and their endeavors which are supposed to be employed in order to achieve such goals (Koh, 1996). For these goals the entrepreneurs are expected to possess a certain level of self-confidence (Robinson et al., 1991a). The importance of self-confidence is necessitated by Koh, (1992) by stating that self-confidence is an integral psychological constituent in entrepreneurial success. It is a common proposition that entrepreneurs are expected to score relatively higher than nonentrepreneurs self-confidence. (Ho and Koh, 1992, Robinson et al., 1991a).

Locus of Control was first proposed by Rotter (1966). It is an Individual's perception of his or her ability to exercise control over the environment. Internals believe that they have control over their environment. Externals view their lives as controlled by external factors. It has been emphasized as an important distinguishing feature of entrepreneurs by many including Hornaday and Aboud, (1971) and Miller, (1983). Since locus of control depicts the reasons of good and bad events in one's life. It is a general proposition that individuals with internal locus of control are more likely to be good organizers and hence good entrepreneurs. On the other hand, entrepreneurs are generally seen as relatively more or moderate risk takers as successful entrepreneurship involves bold decisions in some cases.

Schumpeter (1954) acknowledges J. S. Mill for publicizing the term risk-taking among economists. Mill (1848) included 
risk-taking as a function of entrepreneur. It is the propensity to take chances in the face of loss. Entrepreneurs' preference for moderate level of risks is also emphasized by many others including McBer and Co., 1986.

Dyer (1996) and Kwon and Suh (2004) emphasized the importance of trust in the success of the business. Trust is the general probability that another person should be relied upon in his or her commitments (Rotter, 1967); (Morgan and Hunt 1994). Since, trust is an abstract concept; it can be defined in various perspectives as per the need of the author. In our case, we would talk about the business trust, as all business transactions include trust at some level (Huang and Wilkinson, 2006). The business trust between the business stakeholders including customers, suppliers and employees develops over a period of time. As in businesses, many parties are involved which are mostly interdependent and besides that their also involves factor of uncertainty. That's why; trust is mostly needed in such cases (Huang et al., 2006). Trust is actually the assurance of expectations from both parties. In classical view, trust is the general probability that another person should be relied upon in his or her commitments (Rotter, 1967). Morgan and Hunt (1994) consider trust in a situation where one party is sure about the commitment of exchange of other party. Lyman, (2003) proposed three qualities of trust, these are: trust is rooted in the ability of an individual to consider others as credulous, they will do what they promise and they will stay ethical in business transactions. As stated earlier, trust is the name of reliance on your colleagues, subordinates and off courses other business stakeholders. Since trust is based on probability, therefore it can be regarded as a business risk. As a conclusion it can be inferred that trust is a crucial factor in businesses and social relationships. In businesses it can act as a source of cohesion between the team members or employees and other business stakeholders. While in social relationships, trust is important to sustain such good relations. Traditionally, businesses have faced serious problems due to breach of trust which have also led to inefficient governance. Based on the importance of trust in business, Spekman (1988) regard it as "the cornerstone of strategic partnership". It was also found that trust deficiency can affect the stakeholder's commitment and also the overall business success. Similarly, Morgan et al. (1994) asserts that relationship, commitments and the overall success, both are based on high levels of trust. Dyer (1996); Kwon and Suh (2004) also emphasized the importance of trust in the success of the business. It was concluded that business success is dependent on high trust levels among the business stakeholders. On the other hand, Huang and Wilkinson (2006) proposed a research model regarding trust which shows that trust has a direct relation with business generally and its success more specifically.

Effects of society in shaping an individual's decision regarding choosing business rather than being an employee are really important aspects of entrepreneurship. It is an important factor for the entrepreneurial success (Gnyawali and Fogel, 1994). Societal impacts refer to the effects of society in shaping an individual decision regarding choosing business rather than being an employee, it is also regarded as a crucial factor regarding the entrepreneurial success. It was also inferred that societal factors may be as important as technical assistance, information and credit availability. Similarly, Mokry (1988) regard local communities as an important element in developing entrepreneurial activities. Lui and Wong (1994) suggested that the Hong Kong's economy is prone to Chinese nationals because: the economic development over the years have led towards opening many business opportunities and these opportunities are in the form of small businesses which are more useful to ordinary individuals. On the other hand, adverse public attitude in Czech and Slovak Republics discouraged entrepreneurs (Swanson \& Webster, 1992). They also suggested that developing a social bias against entrepreneurs, may result into social injustice. Relatives, close friends and family members can help the entrepreneur in resources allocation, credit raising, utilizing social contact and help in various decisions making (Kao, 1993). Social norms along with cultural attitude may also lead to efficient business development (Grundsten, 2004). Scholten et.al, (2004) believe that perceptions about the entrepreneurship have a direct positive impact on entrepreneurial intent. Those cultures which support entrepreneurship; develop proper mechanisms to encourage it (Vesper, 1983). Contrary to that, Lui and Wong

THEORETICAL FRAMEWORK
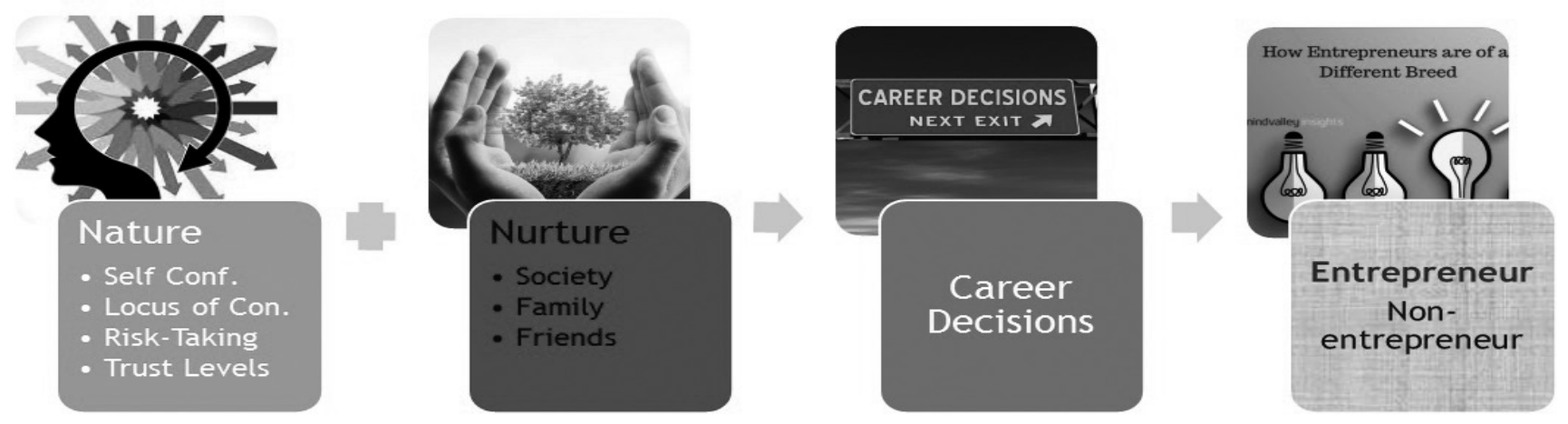

Figure 1. Theoretical Framework 
(1994) proposes the cultural value assessment contradicts the proposition of "strategizing behavior". Strategizing behavior is the behavior which focuses on the attainment of goals through the use of strategic actions. This notion is also sustained by Stites (1985). A study carried out on Taiwanese industrial workers concluded that the Chinese business ethics are more trustworthy, that emphasizes the gap between cultural value assessment and strategizing behaviors (Harrell[s, 1985). People around and individual can have a strong positive impact on the individual in involving in an entrepreneurial activity. For instance in China, entrepreneurs are seen more likely to encourage people around him/her to initiate their own entrepreneurial ventures. Besides that these individuals are also motivated by their close friends, relatives and family members (Kao, 1993; Siu \& Martin, 1992).

\section{RESEARCH QUESTION:}

What differentiates the entrepreneurs from nonentrepreneurs on nature and nurture?

\section{RESEARCH DESIGN AND METHODOLOGY}

A sample size of total of 155 respondents was selected, 70 among them were entrepreneurs while 85 were nonentrepreneurs. The data was collected in the geographical limits of Rawalpindi and Islamabad, Pakistan. Entrepreneurs- for this study are defined as individuals who started their business and secured a peculiar growth from their counter-parts in the first two years through innovation or those individuals who have survived their business in the first five years of their entrepreneurial careers. Data collection has been carried out through a detailed questionnaire. All questions regarding the five independent variables are on 5-point Likert-scale; while the demographic section is placed separately.

In order to check the internal consistency, reliability analysis was conducted for five predictor variables of the instrument.
The results were found acceptable. The cronbach alpha for predictor variables were, $0.83,0.77,0.81,0.76$ and 0.80 for locus of control, risk taking propensity, societal impacts, selfconfidence and trust levels respectively. The data collection was carried through personal administration. As, it is likely to increase the responsiveness of the respondents. Personal administration also includes relatively more involvement of the researcher and the respondent. As, in few cases the respondents were not educated enough to understand the contents of the question therefore the researcher had to guide the respondent throughout the data collection phase. A reasonable effort was made to obtain unbiased responses for the questions in the questionnaire. The data analysis is divided into two sections, first section is the data description while in second section a discriminant analysis is used to find out the significantly discriminating independent variables in two groups- entrepreneurs and non- entrepreneurs.

\section{RESULTS}

The demographic analysis showed that majority of the sampled respondents lived in urban or semi-urban areas (74.3 percent). Most of the respondents were male ( 94 percent) therefore, the sample was skewed for gender. Gender is taken as a control variable in this study as men in general, are relatively more encouraged to start their business while, the females generally, prefer to stay at home and assume the responsibilities as house-wives. Similarly, education was also considered as the control variable. As, most of the educated individuals were considered to be more inclined toward employment in banking and other professions than entrepreneurship.

Table 1 shows that entrepreneurs and non-entrepreneurs are significantly discriminated in terms of societal impacts, risk taking propensity and trust levels. However, locus of control and self-confidence were statistically insignificant in differentiating between entrepreneurs and non-entrepreneurial groups.

\section{Results Descriptive Statistics}

\begin{tabular}{|c|c|c|}
\hline & $\begin{array}{l}\text { Entrepreneurs' } \\
\text { Ownership Type }\end{array}$ & \\
\hline Business Type & No. of Respondents & Percentage \\
\hline Restaurant & 23 & $32.90 \%$ \\
\hline $\begin{array}{l}\text { Grocery } \\
\text { Retailer }\end{array}$ & 14 & $20 \%$ \\
\hline Pharmacy & 13 & $18.60 \%$ \\
\hline Real Estate & 7 & $10 \%$ \\
\hline $\begin{array}{c}\text { Software } \\
\text { House }\end{array}$ & 5 & $7 \%$ \\
\hline Education & 3 & $4.20 \%$ \\
\hline Fitness & 3 & $4.20 \%$ \\
\hline Catering & 2 & $3 \%$ \\
\hline Total & 70 & $100 \%$ \\
\hline
\end{tabular}

\section{Non-Entrepreneurs Employment Type}

$\begin{array}{cc}\begin{array}{c}\text { Employment } \\ \text { Type }\end{array} & \text { No. of Respondents } \\ \text { Teaching } & 18 \\ \text { Banking } & 13 \\ \text { Medicine } & \\ \text { (Doctors) } & 9 \\ \text { Unemloyed } & 16 \\ \text { Others } & 29 \\ \text { Total } & 85\end{array}$

Figure 2. Descriptive Statistics 
Table 1

T-Analysis of Entrepreneurs and Non-Entrepreneurs on Study Variables $(N=155)$

\begin{tabular}{|c|c|c|c|c|c|c|}
\hline \multicolumn{2}{|c|}{$\begin{array}{c}\text { Entrepreneurs } \\
\quad(\mathrm{n}=70)\end{array}$} & \multicolumn{2}{|c|}{$\begin{array}{l}\text { Non-entrepreneurs } \\
\quad(\mathrm{n}=85)\end{array}$} & \multicolumn{2}{|c|}{$95 \%$ CI } & \multirow{2}{*}{$\begin{array}{c}\text { Cohen's } \\
\text { D }\end{array}$} \\
\hline Variables & M(SD) & M(SD) & $t(155)$ & $\mathbf{L L}$ & UL & \\
\hline TL & $3.1(0.6)$ & $3.3(0.7)$ & $2.49 *$ & 0.43 & 0.05 & .35 \\
\hline RTP & $3.0(0.6)$ & $3.3(0.7)$ & $3.1^{*}$ & 0.49 & 0.11 & .45 \\
\hline $\mathrm{LC}$ & $3.5(0.5)$ & $3.7(0.9)$ & 0.6 & 0.29 & 0.18 & .08 \\
\hline $\mathrm{SC}$ & $3.3(0.7)$ & $3.3(0.8)$ & 0.4 & 0.26 & 0.16 & .06 \\
\hline SI & $2.7(0.6)$ & $2.4(0.7)$ & $3.8^{*}$ & 0.09 & 0.51 & .45 \\
\hline
\end{tabular}

Note: CI - Confidence Interval; LL - Lower Limit; UL - Upper Limit; SC = Self-confidence, LC=Locus of control, RTP=Risk taking propensity, $T L=$ Trust levels, $S I=$ Societal impacts $p<.05$.

Table 2 indicates that entrepreneurial entry decisions are highly correlated with societal impacts, self-confidence, and risk taking propensity. The table also illustrates that societal impacts, self-confidence, trust levels and risk taking propensity have a positive effect on entrepreneurial career decisions while locus of control is negatively correlated with entrepreneurial entry decisions. Similarly, self-confidence and societal impacts are also positively correlated with each other while risk taking propensity and locus of control are negatively related with each other.

Table 2

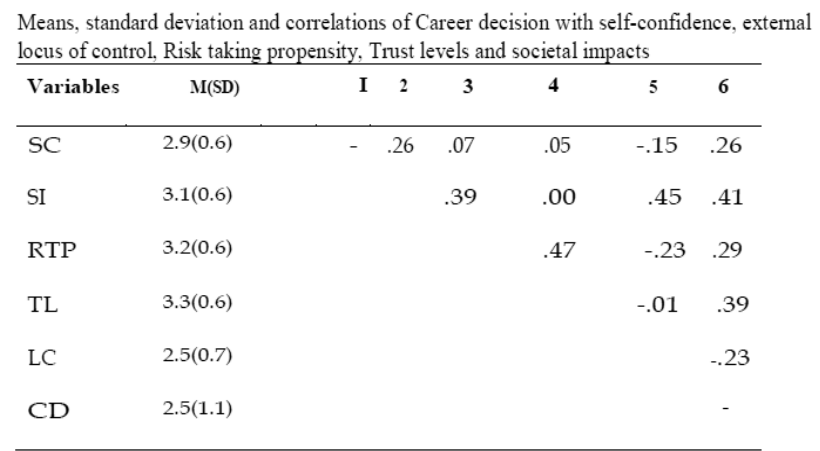

Note. Cl - Confidence Interval; LL - Lower Limit; UL - Upper Limit; SC=Self Confidence, LC=External locus of control, $R T P=$ Risk taking propensity $T L=$ Trust Levels, $S I=$ Societal impacts, $C D=$ Career decision " $p<.05 . "{ }^{\prime} p$
$<.01 . \mid$

It is also evident from table 2 that the relationship between career entry decisions with societal impacts and trust levels is positively significant while locus of control is negatively related with career decision. However, the impact is observed to be insignificant. It is inferred that the individuals who choose to be entrepreneurs are relatively more risk raking as compared to non-entrepreneurs. As starting own business means increasing your risk levels, however, the reward is more appealing that is in the form of more financial freedom and independence. Hence entrepreneurship demonstrates a risk in itself. When the entrepreneurs look at the rewards and still undergo the entrepreneurial decision, it reveals relatively high level of optimism. The score for locus of control is less than 3 in all cases. It depicts that the individual's entrepreneurial entry decisions are not affected by the fact that they "Attribute others for good and bad events in their lives." Societal impacts have an overall mean of more than 3 , showing that the sampled respondents are significantly influenced by the society in general and by friends, family \& relatives specifically. It also shows that the society provides material resources and moral support to the entrepreneurs, hence encouraging them to initiate their own businesses. A higher mean score on self-confidence exhibits individual willingness to get more independence and a need for achievement. As evident from the correlation matrix, trust level is highly correlated with an individual's risk taking propensity. It justifies the notion that trusting people in business illustrates a risk in itself. That's why entrepreneurs have scored high on risk taking propensity.

\section{DISCRIMINANT ANALYSIS}

A discriminant analysis is normally used when the dependent variable is on dichotomous (nominal) scale while independent variables are on ordinal scale. Since the entrepreneurial entry decisions are represented on a dichotomous scale- entrepreneurs and non-entrepreneurs. Therefore, a step-wise discriminant analysis has been used in this study. Notably, entrepreneurs' group is represented by a numeric value of 1 while the non-entrepreneurs are represented by a numeric value of 0 . The analysis is carried out to estimate significant and insignificant variables for the two groups- entrepreneurs and non-entrepreneurs.

Table 3 provides the significant variables with their respective canonical discriminant coefficients and Wilk's lambda statistics.

\section{Table 3}

Canonical, Standardized Canonical Discriminant, Structure Matrix Coefficients, and Wilk's Lambda in Discriminant Analysis for Entrepreneurs and non-entrepreneurs $(\mathrm{N}=155)$

\begin{tabular}{lccccl}
\hline Variable & $\psi$ & $\boldsymbol{\Phi}$ & $\mathbf{r}$ & Wilk's lambda & $\mathbf{p}$ \\
\hline SI & .47 & .71 & .78 & .92 & .02 \\
RTP & .41 & .65 & .61 & .89 & .04 \\
TL & .43 & .61 & .71 & .87 & .05
\end{tabular}

Note. $\psi=$ Standardized Canonical Discriminant Coefficient; $\phi=$ canonical Discriminant function coefficient; $r=$ Structure matrix coefficient; $>=$ Wilk's Lambda $; C A=$ Societal impacts; $R T P=$ Risk taking propensity, $T L=T r u s t$
Levels Levels 
Table. 3 demonstrates that Societal impacts, risk taking propensity and trust levels are significantly discriminating among the two groups- i.e. entrepreneurs and nonentrepreneurs. It can be deduced from this study that, Societal impacts, risk taking propensity and trust levels might have initially induced the individuals to take different decisions like starting own venture or working for someone else. The t-values also indicate a relatively more importance of the variables. A study of group centroids is necessary in order to elaborate the discriminant function. The centroid values were .301 and -.27 for entrepreneurs and non-entrepreneurs respectively. It suggests that values closer to .301 would be related to entrepreneurs while those near to -.27 belong to the non-entrepreneurial group. The cutoff score (-.0015) being the average of two centroids, indicates that individuals who score below the cut off value on societal impacts, risk taking propensity and trust levels are more likely to belong to the non-entrepreneurial group. Or contrary to that, if the score is high than the cutoff value then there is a probability that the individual belongs to the entrepreneurial group.

\section{DISCUSSION}

The present study focuses on effect of the factors such as self-confidence, locus of control, risk taking propensity, societal impacts, and trust levels on the career entry decisions of individuals in Pakistan. By employing step-wise discriminant analysis, a good model fit was given in order to know about the differentiating factors among entrepreneurs and non-entrepreneurs. The most distinguishing factor among entrepreneurs and non-entrepreneurs was societal impacts. Likewise, among the psychological factors risk taking propensity and trust levels were also found as important discriminators. Self-confidence was found to be positively related while locus of control was negatively correlated with entrepreneurial entry decisions. The correlation matrix indicated that risk taking propensity and trust levels were negatively correlated with each other. A moderate risk taking is normally seen in the entrepreneurs, this study has also validated the results of previous studies (Hornaday \& Aboud, 1971; Miller, 1983). Since trust levels were also related with risk taking propensity, trust levels were also found as a significant discriminator in this study (Morgan and Hunt, 1994; Huang and Wilkinson, 2006). Similarly, the effect of Societal impacts was also in line with the findings from the literature (Gnyawali and Fogel ,1994; Mokry ,1988; Lui and Wong 1994). As a limitation, this study has not incorporated many other variables that may also differentiate entrepreneurs from non-entrepreneurs. Future studies are expected to enhance the scope of such studies by including such other variables.

The study at one hand is constrained by various limitationsthe current sample size was relatively small. A larger sample size is recommended for an extended generalizability. Similarly, this study was bound to the geographical limits of Rawalpindi and Islamabad, Pakistan so future studies should also include other geographical areas. Besides, a sound effort was made to get unbiased results; biasness in certain cases cannot be avoided.

\section{CONCLUSION}

Predicting an individual's chances of entrepreneurial entry decisions based on merely psychological characteristics is not sufficient therefore; this study has also included the contribution of societal impacts on entrepreneurial decisions. Hence, It is concluded from this study that although the five independent variables namely- self-confidence, locus of control, societal impacts, trust levels and risk taking propensity were important, however results of this study indicate that societal impacts, risk taking propensity and trust levels were significantly discriminating among the two groups- the entrepreneurs and non-entrepreneurs in terms of entrepreneurial entry decisions. This study is rather more helpful for economic decision makers in terms of igniting economic growth through entrepreneurship. Similarly, it is also evident from the study that the availability of a conducive environment can substantially increase the entrepreneurship rates in the country.

\section{ACKNOWLEDGEMENTS:}

We acknowledge the efforts and cooperation of Mr. Ishtiaq Ahmed. his extended support enabled us to conduct the study.

Technical support of Mr. Hassan Raza (Lecture, NUML, Islamabad, Pakistan) is highly appreciated. He helped us throughout the data analysis and interpretation.

\section{REFERENCES}

Ahmed, S. (1985). "n Ach, risk aversion propensity, locus of control and entrepreneurship", Personality and Individual differences, 6, 781-791.

Andrea Asoni, (2011, "Intelligence, Self-confidence and Entrepreneurship" IFN Working Paper No. 887, 2011, Research Institute of Industrial Economics (IFN)

Asoni, Andrea, What Drives Entrepreneurship?" Unpublished Manuscript (2011), University of Chicago.

Begley, T.M. \& D.P. Boyd (1987). "Psychological characteristics associated with performance in entrepreneurial firms and smaller businesses", Journal of Business Venturing, 2, 79-93.

Bhide, Amar (2000) The Origin and Evolution of New Businesses, Oxford University Press, London.

Broehl, W.G. (1978). The Village Entrepreneurs. Cambridge: Harvard University Press.

Bruyat, C. and Julien, P.A. (2001). "Defining the field of research in entrepreneurship", Journal of Business Venturing, 16(2), 165-80. Owoseni, O.O. and Akanbi, P.A. (2010). Entrepreneurial Intentions: A Theoretical Framework. Journal of Management and Corporate Governance, (1): 115.

Card, David, Using geographic variation in college proximity to estimate the return to schooling", in L. N. Christo_des, E.. K. Grant and R. Swidinsky (Eds.), Aspects of labour mar- 
ket behaviour: essays in honor of John Vanderkamp (Toronto, Canada: University of Toronto Press, 1995).

Carree, M.A. and Thurik, A.R. (2003). "The impact of entrepreneurship on economic growth", in Audretsch, D.B. and Acs, Z.J. (Eds), Handbook of Entrepreneurship Research, Kluwer Academic, Boston, MA/Dordrecht, 437-471.

Changing Minds (2012). http://changingminds.org/explanations/trust/what is trust.htm. Access on 20th June 2012.

Cochran, T. (1971) “The Entrepreneur in Economic Change”, in Entrepreneurship and Economic Development, The Free Press.

Dart, J. (1971). "The development of a classification system for entrepreneurial types with a special investigation of the potential of Achievement Motivation and its correlates to discriminate between these types", DBA dissertation, University of Colorado, Boulder.

Davidsson, P. (1989). Continued entrepreneurship and small firm growth, EFI, Stockholm, Ekonomiska Forsknings Institute.

Dyer, J.H. (1996), "How Chrysler Created an American Keiretsu," Harvard Business Review.pp. 42-56.

Eberwein, Curtis, John C. Ham and Robert J. LaLonde, IThe Impact of Being Offered and Re- ceiving Classroom Training on the Employment Histories of Disadvantaged Women: Evidence from Experimental Data", Review of Economic Studies 64:4 (1997), 655-682.

Fracaro, K.E. (2008). Keys to Attaining Employee Trust. Professional Development. http://www.ncmahq.org/files/

Articles/CM0808\%20-\%20Professional\%20Development.pdf. Access on 20th June 2012.

Gartner, W.B. (1989), “’Who is an entrepreneur?' Is the wrong question" Entrepreneurship Theory and Practice, 5, 47-67.

Gibb, A.A. (2002a). In pursuit of a new 'enterprise' and 'entrepreneurship' paradigm for learning: creative destruction, new values, new ways of doing things and new combinations of knowledge. International Journal of Management Reviews, 4(3), 233-269.

Gnyawali, R., \& Fogel, D.S. (1994). Environments for entrepreneurship development: Key Dimension. Entrepreneurship Theory Practice, 18(4), 43-62.

Grundsten, H. (2004). Entrepreneurial Intentions and the Entrepreneurial Environment. A Study of Technology-Based New Venture Creation, Doctoral dissertation. Helsinki University of Technology, Finland.

Hall, D.T. (2002). Careers in and out of Organizations, Sage Publications, Thousand Oaks, CA.

Ham, John C. and Robert J. LaLonde, IThe E_ect of Sample Selection and Initial Conditions in Duration Models: Evidence from Experimental Data on Training" Econometrica 64:1 (1996), 175-205

Harrell, S. (1985). Why do the Chinese work so hard? Reflections on an entrepreneurial ethic. Modern China, 11(2), 203-26.

Hisrich R.D. and Peters, M.P. (2006). Entrepreneurship. NewDelhi: Tata McGraw-Hill Company Limited.

Hood, J.N. \& J.E. Young (1993). "Entrepreneurship's areas of development: a survey of top executives in successful firms", Journal of Business Venturing, 8(1), 115-135.

Hornaday, J.A. \& J. Aboud (1971), “Characteristics of success- ful entrepreneurs.” Personnel Psychology, 24: 141-153.

Hornaday, J.A. and Bunker, C. S. (1970). The Nature of the Entrepreneur. Personnel Psychology, 23: 47- 54.

Hornaday, R. H. (1992). Thinking about entrepreneurship: A fuzzy set approach. Journal of Small Business Management, 30(4): $12-24$.

Huang, Y., and Wilkinson, I. F. (2006). Understanding power and trust in interfirm relationships: A dynamic perspective. Pp.1-13

Iyer, Rajkamal and Antoinette Schoar (2007), "Are There Cultural Determinants of Entrepreneurship?" Sloan Business School, MIT, working paper.

Kao, J. (1993). The worldwide web of Chinese business. Harvard Business Review, MarchApril, 24-36.

Kazmi, S. Z., Abbas, \& Nabradi, A. (2017). New Venture Creation - The Influence of Entrepreneurship Education on Students'. APSTRACT - APPLIED STUDIES IN AGRIBUSINESS AND COMMERCE, 11(1-2), 147-154. doi:10.19041/APSTRACT/2017/1-2/18

Khanka, S. S. (2005). Entrepreneurial Development. Ram Nagar, New-Delhi: S. Chand and Company Limited.

Koh, H. C. (1996). Testing hypotheses of entrepreneurial characteristics: A study of Hong- Kong MBA students. Journal of Managerial Psychology, 11 (3): 12-25.

Korunka, C., Frank, H., Lueger, M., \& Mugler, J. (2003). The entrepreneurial personality in the context of resources, environment, and the startup process-A configurational approach. Entrepreneurship Theory and Practice, 28 (1): 23-42.

Kwon, I.W.G., \& Suh, T. (2004), "Factors affecting the level of trust and commitment in supply chain relationships" The Journal of Supply Chain Management: A Global Review of Purchasing and Supply, pp.4-20

Lazear, E. (2002) "Entrepreneurship" Working paper 9109, National Bureau of Economic Research, Cambridge, Massachusetts.

Liles, P.R. (1974). New business venture and the entrepreneur. Irwin, Homewood, III.

Lorrain, J \& L. Dussault (1988). Relation between psychological characteristics, administrative behaviors and success of founder entrepreneurs at the start-up stage. Frontiers of Entrepreneurship Research: 150-164.

Low, M. B., \& MacMillan, I. C. (1988). Entrepreneurship: Past research and future challenges. Journal of Management, 14(2): 139-161.

Lui, T. L., \& Wong, T.W.P. (1994). Chinese Entrepreneurship in Context, Hong Kong: Hong Kong Institute of Asia-Pacific Studies, the Chinese University of Hong Kong, Hong Kong.

Lumpkin, G.T., \& Dess, G. G. (1996). Clarifying the entrepreneurial orientation construct and linking it to performance. Academy of Management Review. 21(1): 135-172

Lyman, A. (2003). Building trust in the workplace: Why trust brings out the best in your employees. Great Place Work institute, Melcrum Publishing Ltd, 3(1), pp.24-27. 15

McClelland, D. (1961) The Achieving Society, Princeton: D. Van Nostrand.

McClelland, D. C. (1961). The achieving society. Princeton, NJ: Van Nostrand . 
McGhee, P.E and V.C. Crandall. (1968) "Beliefs in Internal-External Control of Reinforcement and Academic Performance", Child Development.

Mealli, Fabrizia and Stephen Pudney, Occupational Pensions and Job Mobility in Britain: Estimation of a Random-Effects Competing Risks Model” Journal of Applied Econometrics 11:3 (1996), 293-320

Mengel, R.H. (1972).Entrepreneurship in microelectronic industry. Doctoral dissertation, University of Texas, Austin.

Meyer, H.H., Walker, W.B. \& Litwin, G.H. (1961).”Motive patterns and risk preferences associated with entrepreneurship.” Soc. Psychol., 63: 570-574.

Miller, D., \& Friesen, P (1978). Archetypes of strategy formulation. Management Science, 24: 921- 933.

Mokry, B.W. (1988). Entrepreneurship and Public Policy: Can Government Stimulate Business Startups? New York: Quorum Books.

Morgan, R.M. \& Hunt, S. D. (1994). "The Commitment-Trust Theory of Relationship Marketing" Journal of Marketing, (58), July 1994, pp. 20-38.

Morgan, R.M. \& Hunt, S. D. (1994). "The Commitment-Trust Theory of Relationship Marketing" Journal of Marketing, (58), July 1994, pp. 20-38.

Owoseni Omosolape Olakitan and Akanbi Paul Ayobami, (2011) "An Investigation of Personality on Entrepreneurial Success" Journal of Emerging Trends in Economics and Management Sciences (JETEMS) 2 (2): 95-103, ${ }^{\circ}$ Scholarlink Research Institute Journals, 2011 (ISSN: 2141-7024)

Perry, C., R. MacArthur \& B. Cunnington (1986). Need for achievement and locusof control of Australian small business owner-managers and super entrepreneurs. International Small Business Journal, 4 (4): 55-64.

Rauch, A., \& Frese, M. (2000). Psychological approaches to entrepreneurial success: A general model and an overview of findings. In C. L. Cooper \& I. T. Robertson (Eds.), International Review of Industrial and Organizational Psychology :101142.

Robinson, P.B., Stimpson, D.V., Huefner, J.C., Hunt, H.K. (1991a), "An attitude approach to the prediction of entrepreneurship", Entrepreneurship Theory and Practice, Vol. 15 No.4, pp.13-32.

Rotter, J. B. (1967), "A New Scale for the Measurement of Interpersonal Trust". Journal of Persoanlity, Vol.35(4), 651-665.

Sandberg, W.R. \& Hofer, C.W. (1987). Strategy, industry structure and the entrepreneur. Journal of Business Venturing, (2): 25-28.

Scholten, V., Kemp, R., \& Omta, O. (2004). Entrepreneurship for Life: The Entrepreneurial Intention among Academics in the Life Sciences, Paper presented at the 2nd European Summer University Conference 2004, Enschede, The Netherlands, pp. 1-15.

Sexton, D.L. \& N.B. Bowman (1983). "Comparative Entrepreneurship Characteristics of Students". In J. Hornaday, J.Timmons, \& K. Vesper (Eds.), Frontiers of Entrepreneurship Research. Wellesley, MA: Babson College: 465-478.

Simeon Djankov Yingyi Qian Gérard Roland Ekaterina Zhuravskaya ,(2007) "What Makes a Successful Entrepreneur? Evidence from Brazil". Available at: http://eml.berkeley. edu/ groland/pubs/brazilent0907.pdf
Siu, W., \& Martin, R. G. (1992). Successful entrepreneurship in Hong Kong. Long Range Planning, 25(6), 87-93. 16

Spekman, R.E. (1988), "Strategic Supplier Selection: Understanding Long-Term Buyers Relationship," Business Horizon, pp. 75- 81 .

Stites, R.W. (1985). Industrial work as an entrepreneurial strategy. Modern China, 11(2), 227-46.

Swanson, D., \& Webster, L. (1992). Private sector manufacturing in the Czech and Slovak Republic: A survey of firms. Washington, DC: The World Bank.

Vesper, K. H. (1980). New venture strategies. Englewood Cliffs, NJ: Prentice Hall.

Young, Frank W. (1971) "A Macro sociological Interpretation of Entrepreneurship", in Entrepreneurship and Economic Development, The Free Press.

Kates, S. (2015) Origin and Evolution of the Term" Entrepreneur" in English. 